\title{
Prediction of pathological complete response and prognosis in patients with neoadjuvant treatment for triple-negative breast cancer
}

Paul Gass ${ }^{1 *}$ D, Michael P. Lux', Claudia Rauh, Alexander Hein ${ }^{1}$, Mayada R. Bani ${ }^{1}$, Cornelia Fiessler ${ }^{2}$, Arndt Hartmann ${ }^{3}$, Lothar Häberle ${ }^{1,4}$, Jutta Pretscher ${ }^{1}$, Ramona Erber ${ }^{3}$, David L. Wachter ${ }^{3}$, Rüdiger Schulz-Wendtland ${ }^{5}$, Matthias W. Beckmann ${ }^{1}$, Peter A. Fasching ${ }^{1}$ and Marius Wunderle ${ }^{1}$

\begin{abstract}
Background: It has been reported that pathological complete response is an important surrogate marker for disease-free survival and overall survival in patients with triple-negative breast cancer. This study investigates predictors of the response to neoadjuvant platinum-based or anthracycline-based treatment, and of the prognosis, in patients with triple-negative breast cancer.

Methods: A total of 121 patients with triple-negative breast cancer received neoadjuvant treatment with either platinum or anthracycline between 2008 and 2013. Pathological complete response was assessed relative to different treatments using logistic regression models with age, clinical tumor stage, grading, and Ki-67 as predictors and interaction terms, to obtain adjusted and subgroup-specific results. The impact of the pathological complete response rate on disease-free survival and overall survival was also analyzed.

Results: The pathological complete response rate was higher after platinum/taxane treatment compared with anthracycline/taxane (50.0\% vs. 41.8\%), but this was not significant in the adjusted analysis (OR 1.44; $95 \% \mathrm{Cl}, 0.68$ to 3.09). A high histological grade (G3) was a predictor for higher pathological complete response in platinum-based therapy (OR 2.27; 95\% Cl, 1.00 to 5.30). The effect of neoadjuvant chemotherapy on pathological complete response was significantly different for G1-2 vs. G3 $\left(P_{\text {interaction }}=0.013\right)$, and additional subgroup-specific differences were noted. Pathological complete response was a predictor for improved disease-free survival and overall survival in both treatment groups, with and without platinum chemotherapy.
\end{abstract}

Conclusions: This retrospective study of patients with triple-negative breast cancer adds to the evidence that the treatment effect of platinum may be greatest particularly in G3 tumors. In addition, the effect of pathological complete response on the prognosis does not depend on the treatment used.

Keywords: Triple-negative breast cancer, Neoadjuvant therapy, Platinum, Pathological complete response, Prognosis, Prediction

\footnotetext{
*Correspondence: paul.gass@uk-erlangen.de

'Department of Gynecology and Obstetrics, Erlangen University Hospital,

University Breast Center for Franconia, Comprehensive Cancer Center

Erlangen-EMN, Friedrich Alexander University of Erlangen-Nuremberg,

Universitätsstrasse 21-23, 91054 Erlangen, Germany

Full list of author information is available at the end of the article
}

(c) The Author(s). 2018 Open Access This article is distributed under the terms of the Creative Commons Attribution 4.0 International License (http://creativecommons.org/licenses/by/4.0/), which permits unrestricted use, distribution, and reproduction in any medium, provided you give appropriate credit to the original author(s) and the source, provide a link to the Creative Commons license, and indicate if changes were made. The Creative Commons Public Domain Dedication waiver (http://creativecommons.org/publicdomain/zero/1.0/) applies to the data made available in this article, unless otherwise stated. 


\section{Background}

Breast cancer $(\mathrm{BC})$ is the most frequent type of cancer in women, with approximately 70,000 new cases in Germany per year [1]. There has been substantial improvement in the prognosis and treatment of $\mathrm{BC}$; the prognosis depends mainly on the clinical stage, as well as the molecular characteristics of the tumor [2-8]. The international treatment guidelines focus on stage and on these molecular subtypes, which are characterized immunohistochemically as surrogate markers in clinical routine work [8-10]. Basal-like tumors are very similar to immunohistochemically defined triple-negative breast cancer (TNBC), which lacks expression of the estrogen receptor (ER), progesterone receptor (PR), and human epidermal growth factor receptor 2 (HER2) [11-16].

Systemic treatment for TNBC has been restricted mainly to conventional chemotherapy in the past $[8-10,14,17]$, but new targeted therapies such as immune-checkpoint inhibitors [18] and poly-adenosine diphosphate ribose polymerase (PARP) inhibitors $[19,20]$ have been under investigation in clinical trials, which are suitable for subgroups of TNBC patients with a germline $B R C A 1 / 2$ mutation or a homologous recombination deficiency (HRD) in the tumor [7, 14, 21, 22]. Interestingly, TNBC is associated with an increased deoxyribonucleic acid (DNA)-repair defect in the tumor cells, which is caused either by germline mutations in genes such as $B R C A 1 / 2$, $P A L B 2$, and others $[23,24]$ or by a somatic HRD, which can be exploited by systemic therapies [21].

As systemic therapies are limited in patients with TNBC, achieving a pathological complete remission (pCR) continues to be important for a favorable long-term prognosis in these patients, as several studies have reported [7, 25-27]. Higher pCR rates have also been described for TNBC in comparison with other types of $\mathrm{BC}$, especially with platinum treatment [14, 27-36].

Platinum induces DNA damage by cross-linking DNA strands, which leads to cessation of replication and apoptosis of the tumor cell [37-39]. Since TNBC tumors have a limited DNA repair capacity in comparison with other BC subtypes, platinum appears to be an optimal candidate for achieving a high response rate in these tumors [10, 30, 37, 39-42]. However, there is still ongoing debate on whether platinum is the best treatment for different kinds of TNBC or whether an anthracycline-based treatment should be regularly given instead, as recommended in several national and international guidelines $[8,10,14]$.

In the GeparSixto trial (NCT01426880) investigating the effect of adding platinum to doxorubicin/paclitaxel in patients with TNBC and HER2-positive BC, there was a significant increase in the pCR rate in TNBC, from 36.9 to $53.2 \%$, with the addition of platinum (OR 1.94; 95\% CI, 1.24 to $3.04 ; P=0.005)$, while there was no significant effect in HER2-positive BC, at $36.8 \%$ vs. $32.8 \%$ with the addition of platinum (OR 0.841; 95\% CI, 0.511 to $1.39 ; P=0.581$ ) [35]. Another subgroup analysis from the GeparSixto trial demonstrated an increased pCR in TNBC and HER2-positive BC after platinum treatment in tumors with a histological grade 3 [35]. A survival analysis for TNBC patients from the same trial showed a longer 3-year disease-free survival (DFS) rate of $85.8 \%$ vs. $76.1 \%$ for platinum treatment (log-rank test, $P=0.0325$ ) [31]. These findings prompted us to perform the present retrospective analysis and to investigate the influence of molecular and clinicopathological predictors on pCR during platinum vs. anthracycline treatment in patients with TNBC, as well as the impact of the tumor response on survival in these patients.

\section{Methods}

\section{Patient selection}

Patients selected for this study were treated for invasive TNBC with neoadjuvant chemotherapy at the University Breast Center of Franconia at Erlangen University Hospital between 2008 and 2013. During this time, a total of 2868 patients were treated for invasive BC at the hospital. Patients without TNBC $(n=2546)$ were excluded, as were patients who did not receive neoadjuvant chemotherapy $(n=191)$ or who did not receive combination therapy with at least platinum/taxane or anthracycline/taxane $(n=10)$. The final group consisted of 121 patients with unilateral tumors.

\section{Clinical data}

All characteristics of the patients and tumors were documented as part of the certification processes required by the German Cancer Society (Deutsche Krebsgesellschaft) and by the German Society for Breast Diseases (Deutsche Gesellschaft für Senologie e.V.) [43, 44]. For certification, tumor characteristics, treatment data, histopathological characteristics, tumor treatments, and follow-up data have to be documented and are audited annually for each preceding year.

\section{Pathological data on molecular subtypes}

All of the histopathological information used in the analysis was directly documented from the original pathology reports, which were reviewed by two investigators. Tumor grade, ER status, PR status, HER2, and Ki-67 proliferation status were assessed as follows. Grading was determined in accordance with the method described by Elston and Ellis [45]. Monoclonal mouse antibody against estrogen receptor-alpha (clone 1D5, 1: 200 dilution, DAKO, Denmark), monoclonal mouse antibody against the progesterone receptor (clone pgR636, 1: 200 dilution, DAKO, Denmark), and monoclonal antibody against Ki-67 (clone MIB-1, 1: 200 dilution, DAKO, 
Denmark) were stained using an automated immunostainer (Ventana Ultra) on the pretreatment core biopsies. The percentage and intensity of positively stained cells was included in the pathology reports. The cut-off point for high proliferation determined by Ki-67 staining was regarded as more than $35 \%$ positively stained cells, in accordance with a biological analysis presented previously. This cut-off value of Ki-67 was chosen because it distinguished the response to chemotherapy best in TNBC [46]. A polyclonal antibody against HER2 (1: 200 dilution, DAKO, Denmark) was used, and HER2 status was given in the pathology reports as negative, $0,1+, 2+$, or $3+$ in accordance with the published guidelines [47]. Tumors with a score of 0 or $1+$ were regarded as HER2-negative, and those with a score of $3+$ were regarded as HER2-positive. Tumors with a $2+$ staining score were tested for gene copy numbers of HER2 by chromogene in-situ hybridization. Using a kit with two probes of different colors (ZytoDot, 2C SPEC HER2/ CEN17, Zyto Vision Ltd., Bremerhaven, Germany), the gene copy numbers of HER2 and centromeres of the corresponding chromosome 17 were retrieved. A HER2/ CEN17 ratio of $\geq 2.0$ or the presence of $\geq 6$ HER2 signals in the majority of tumor cells was considered as amplification of HER2. Scoring was carried out in a standardized way by a group of dedicated pathologists in routine surgical pathology. The immunohistochemical evaluation of ER, PR, Ki-67, and HER2 and the chromogene in-situ hybridization of HER2 were quality-controlled in accordance with the pathology laboratory's accreditation standards (ISO/DIN 17020, Deutsche Akkreditierungsstelle) and validated successfully by yearly round-robin tests, as required by the German Cancer Society. On the basis of these staining results, patients with negative or low expression $(\leq 10 \%)$ for ER or PR and negative for HER2 were classified as having triple-negative breast cancer (TNBC).

\section{Definition of $\mathrm{pCR}$}

The definition of $\mathrm{pCR}$ is the complete disappearance of all invasive carcinoma cells in the breast and axillary lymph nodes (ypT0/ypN0), which is assessed pathologically in the resected tissue after neoadjuvant chemotherapy [26].

\section{Statistical considerations}

The characteristics of the patients were described using mean and standard deviation (SD) or frequencies and percentages. Logistic regression modeling with interaction terms was performed to estimate the joint effect of chemotherapy and other predictor variables (age at first diagnosis as a categorical variable: $<45$ years vs. $45-54$ years vs. $>54$ years; tumor size before therapy as a categorical variable: $\leq 2 \mathrm{~cm}$ vs. $>2 \mathrm{~cm}$; grading as a categorical variable: 1 and 2 vs. 3; and Ki-67 as a categorical variable: $<36 \%$ vs. $\geq 36 \%$ ) on the pCR. The results are given as odds ratios (ORs) with corresponding 95\% confidence intervals (CIs). DFS times and overall survival (OS) times were analyzed using Kaplan-Meier curves and log-rank tests. $P$ values were not corrected for multiple testing. All analyses were carried out using the $\mathrm{R}$ system for statistical computing (version 3.3.2, 2016; $\mathrm{R}$ Core Team, Vienna, Austria).

\section{Results}

In this group of 121 retrospectively selected patients with TNBC, 66 patients received platinum/taxane-based neoadjuvant chemotherapy and 55 patients received anthracycline/taxane-based neoadjuvant chemotherapy.

The patient characteristics in the anthracycline-treated cohort and platinum-treated cohort were comparable. In the groups receiving anthracycline-based and platinum-based treatment, respectively, the patients' mean age at the time of first diagnosis of $\mathrm{BC}$ was 48.3 years (SD 9.6) vs. 50.3 years (SD 12.1); $81.8 \%$ vs. $84.8 \%$ had histological grade $3 ; 76.4 \%$ vs. $78.8 \%$ had $\mathrm{Ki}-67 \geq 36 \%$; and $63.6 \%$ vs. $59.1 \%$ had tumor sizes $>2 \mathrm{~cm}$. The patients' characteristics are listed in detail in Table 1.

The pCR rates were $41.8 \% \quad(n=23)$ for anthracycline-based treatment and $50 \%(n=33)$ for platinum-based treatment (Table 1). As expected, the pCR rate was higher in patients with clinically smaller tumor sizes, histological grade 3, and higher Ki-67 levels. In addition, $\mathrm{pCR}$ was higher in patients $<54$ years in comparison with patients $>54$ years (Table 2).

For prediction of pCR using a multiple logistic regression model, the OR of platinum treatment vs. anthracycline treatment was $1.44(95 \% \mathrm{CI}, 0.68$ to 3.09$)$. Subgroup analysis for clinical tumor stage, histological grade, and $\mathrm{Ki}-67$ showed a higher $\mathrm{pCR}$ rate for grade 3 tumors after platinum treatment (OR 2.27; 95\% CI, 1.00 to 5.30). Platinum therapy in grade 1 or grade 2 tumors was associated with an inverse effect on the pCR rate (OR 0.09; 95\% CI, 0.00 to 0.76), and the difference in treatment effects for grading (G3 vs. G1/G2) on pCR was statistically significant $\left(P_{\text {interaction }}=0.013\right)$. The other interactions in the subgroups did not show any statistically significant differences (Fig. 1).

Whether or not a pCR was achieved was significantly related to increased DFS both in patients who received platinum-based treatment $(P=0.001)$ and in those who received anthracycline-based therapy $(P=0.002)$. The same was seen in relation to OS ( $P=0.002$ for platinum-based therapy and $P=0.022$ for anthracycline-based therapy) (Figs. 2 and 3).

\section{Discussion}

In this retrospective analysis of neoadjuvantly treated patients with TNBC, no differences were found in the treatment effect of platinum-based chemotherapy and 
Table 1 Patient and tumor characteristics relative to chemotherapy

\begin{tabular}{|c|c|c|}
\hline & Anthracycline/taxane-based & Platinum/taxane-based \\
\hline & $\mathrm{n}(\%)$ or mean (SD) & n (\%) or mean (SD) \\
\hline Overall & 55 & 66 \\
\hline Age at first diagnosis & $48.3(9.6)$ & $50.3(12.1)$ \\
\hline \multicolumn{3}{|l|}{ Age } \\
\hline$<45 y$ & $19(34.5)$ & $21(31.8)$ \\
\hline $45-54$ y & $21(38.2)$ & $19(28.8)$ \\
\hline$>54 y$ & $15(27.3)$ & $26(39.4)$ \\
\hline \multicolumn{3}{|l|}{ Tumor size } \\
\hline$\leq 2 \mathrm{~cm}$ & $20(36.4)$ & $27(40.9)$ \\
\hline$>2 \mathrm{~cm}$ & $35(63.6)$ & $39(59.1)$ \\
\hline \multicolumn{3}{|l|}{ Grading } \\
\hline 1 or 2 & $10(18.2)$ & $10(15.2)$ \\
\hline 3 & $45(81.8)$ & $56(84.8)$ \\
\hline \multicolumn{3}{|l|}{ Ki-67 } \\
\hline$<36 \%$ & $13(23.6)$ & $14(21.2)$ \\
\hline$\geq 36 \%$ & $42(76.4)$ & $52(78.8)$ \\
\hline \multicolumn{3}{|l|}{$\mathrm{pCR}$} \\
\hline No & $32(58.2)$ & $33(50.0)$ \\
\hline Yes & $23(41.8)$ & $33(50.0)$ \\
\hline
\end{tabular}

$p C R$ pathologic complete response, $S D$ standard deviation

Table 2 Pathological complete response rates relative to patient and tumor characteristics

\begin{tabular}{lll}
\hline & $\mathrm{pCR}(\mathrm{no})$ & $\mathrm{pCR}(\mathrm{yes})$ \\
$\mathrm{n}(\%)$ or mean (SD) & $\mathrm{n}(\%)$ or mean (SD) \\
\hline Overall & 65 & 56 \\
Age at first diagnosis & $51.2(11.6)$ & $47.3(10.0)$ \\
Age & & \\
$<45 \mathrm{y}$ & $20(50.0)$ & $20(50.0)$ \\
$45-54 \mathrm{y}$ & $20(50.0)$ & $20(50.0)$ \\
$>54 \mathrm{y}$ & $25(61.0)$ & $16(39.0)$ \\
Tumor size & & \\
$\leq 2 \mathrm{~cm}$ & $21(44.7)$ & $26(55.3)$ \\
$>2 \mathrm{~cm}$ & $44(59.5)$ & $30(40.5)$ \\
Grading & & $7(35.0)$ \\
1 or 2 & $13(65.0)$ & $49(48.5)$ \\
3 & $52(51.5)$ & $8(29.6)$ \\
Ki-67 & & $48(51.1)$ \\
$<36 \%$ & $19(70.4)$ & $23(41.8)$ \\
$\geq 36 \%$ & $46(48.9)$ & $33(50.0)$ \\
Chemotherapy & & \\
Anthracycline + taxane & $32(58.2)$ & $33(50.0)$ \\
Platinum + taxane & & \\
\hline
\end{tabular}

$p C R$ pathologic complete response, $S D$ standard deviation anthracycline-based chemotherapy with regard to pCR for overall TNBC. However, patients with grade 1 or 2 benefited from anthracycline-based chemotherapy whereas patients with grade 3 benefited from platinum-based chemotherapy. Moreover, pCR was a

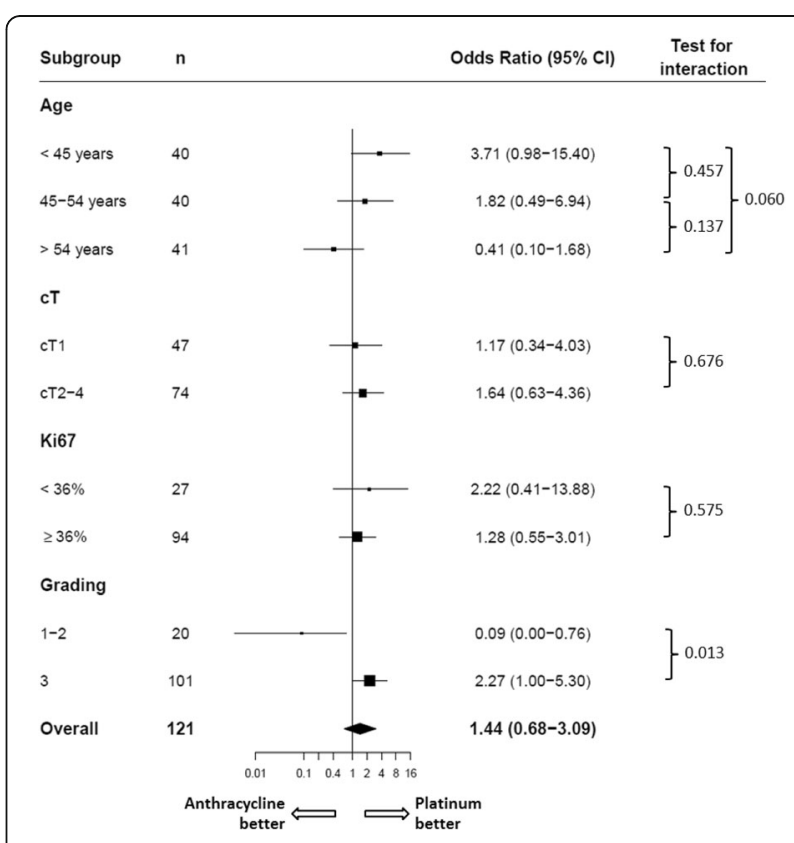

Fig. 1 Forest plot for predicting the rate of pathological complete response to treatment in subgroups 


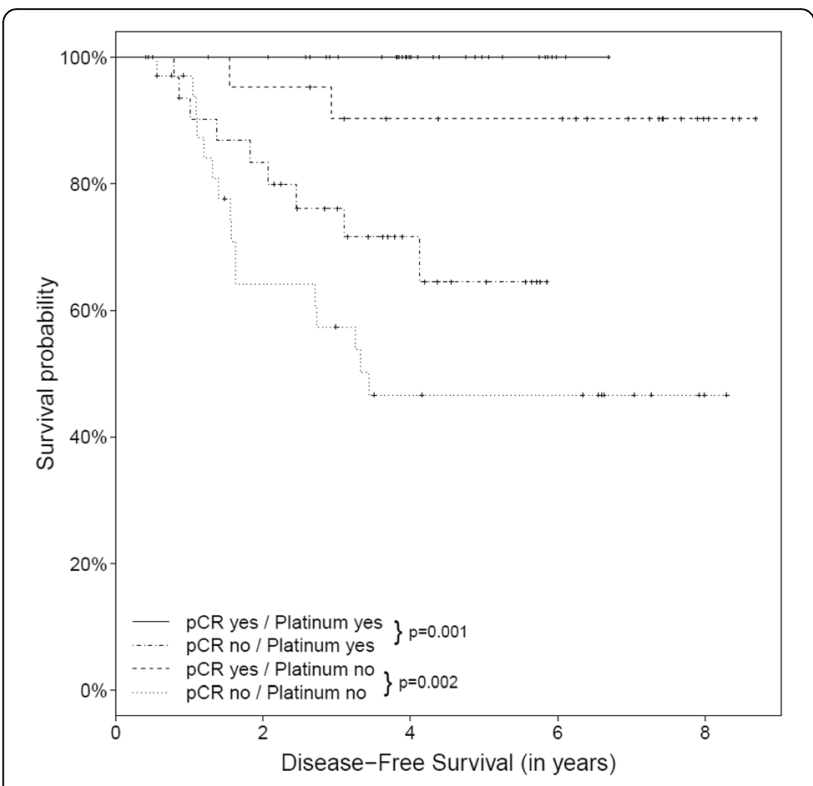

Fig. 2 Kaplan-Meier curves for the effect of treatment and pathological complete response ( $\mathrm{pCR}$ ) on disease-free survival

predictor of DFS and OS, independently of the treatment.

Although multivariate analysis showed that the type of chemotherapy was not statistically significant for the prediction of $\mathrm{pCR}$ in overall TNBC, there was a trend toward a higher $\mathrm{pCR}$ for neoadjuvant platinum-based vs. anthracycline-based therapy. This finding is consistent with several trials that have investigated the effect of different regimens of neoadjuvant chemotherapy in patients with TNBC and have reported higher pCR rates in

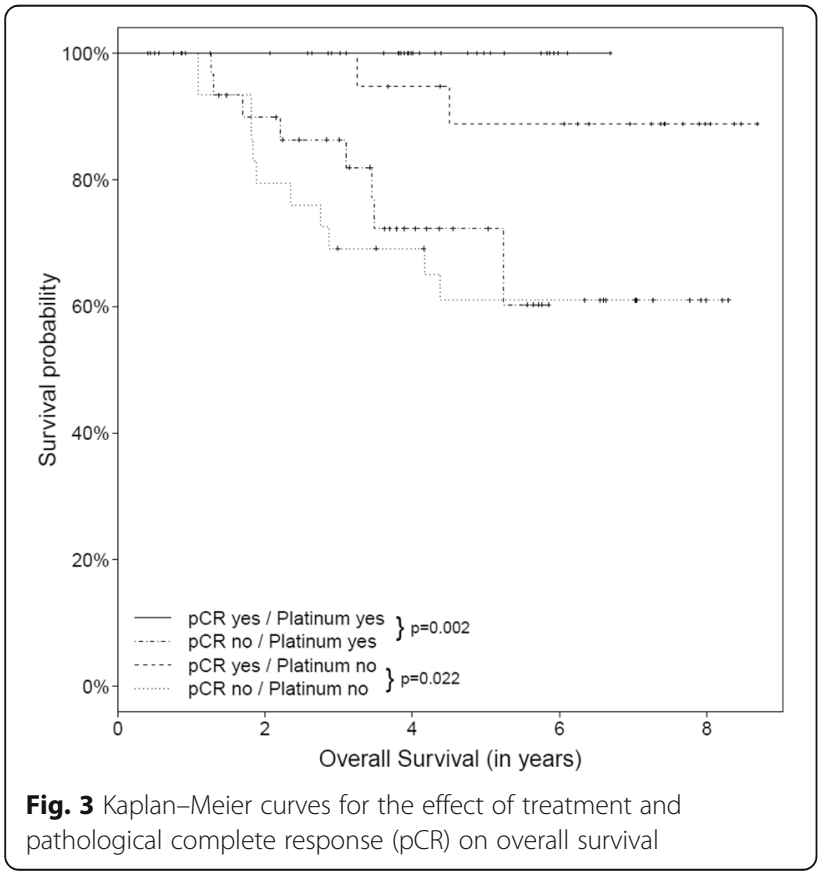

TNBC after platinum treatment in patients with or without $B R C A 1 / 2$ mutations [14, 27-36]. In the present study, histological grade 3 vs. grades $1-2$ was a predictor of high effectiveness with regard to platinum treatment in TNBC patients. There is one subgroup analysis from the GeparSixto trial that showed a significant benefit for histological grade 3 vs. grades $1-2$ if platinum treatment was added in TNBC and HER2-positive BC (OR for G3, 1.73; $95 \% \mathrm{CI}, 1.15$ to 2.60 ; OR for G1-2, 0.776 ; $95 \% \mathrm{CI}$, 0.432 to $1.40 ; P_{\text {interaction }}=0.027$ ) [35]. A high histological grade may either have an independent influence on the tumor's sensitivity to platinum treatment or, more likely, it may be a predictor for molecular characteristics of triple-negative tumor cells that predispose to a better response to platinum treatment, such as a higher mutational spectrum, increased HRD [48, 49], faster growth $[14,16]$, and higher amounts of tumor-infiltrating lymphocytes (TILs) [50, 51].

It has been shown in several publications that $B R C A 1 / 2$ mutations, which are associated with increased DNA repair deficiency $[20,38]$, can be found in at least $10-15 \%$ of all TNBCs $[24,32,52]$, especially in those with a high grade and Ki-67 [24, 53, 54]. For example, an analysis of 1824 patients with TNBC found a BRCA1/2 mutation in $4.9 \%$ of patients with grades $1-2$ and in $13 \%$ of patients with grade 3 [24]. These tumors were also associated with a better response to platinum treatment $[14,29,36,39]$.

HRD can be found in tumors with germline or somatic mutations in BRCA1/2 or in other genes involved in DNA repair [40-42, 48, 49, 55]. In one analysis, the addition of platinum significantly increased the pCR (ypT0is/ypN0) rate from 36.6 to $63.2 \%$ in HRD tumors with intact $B R C A 1 / 2$ function in tumor tissue $(P=0.018)$, marginally from 61.9 to $72.7 \%$ in $B R C A$-mutated tumors $(P=0.406)$, and moderately from 20.0 to $40.7 \%$ in non-HRD tumors $(P=0.086)$. Patients with HRD-positive tumors had a longer event-free survival than non-HRD-deficient ones (hazard ratio $1.805, P=0.0526$ ) [30]. Other studies support greater efficacy - especially of platinum, but also of anthracyclines - in HRD-positive tumors [40-42, 48]. The same molecular deficiency is targeted by PARP inhibitors. These are under investigation in clinical trials for (neo-) adjuvant treatment of $\mathrm{BC}$, which require either a $B R C A 1 / 2$ mutation or a high HRD score for patient inclusion $[8,19,20,22]$. Stronger efficacy of platinum in high-grade TNBC may be explained by the co-occurrence of high grading and increased HRD, either at the germline level or the somatic level, or both [30, 40, 42, 48], although there is limited data on this issue $[48,49]$. In one smaller analysis of $70 \mathrm{TNBC}$ patients, $71 \%$ had an increased HRD score. Seventy-six percent of the patients had G3 tumors, $24 \%$ had G2 tumors, and no patients with G1 tumors were included in this dataset [48]. 
It has been shown that $\mathrm{Ki}-67$ is a useful prognostic factor in BC $[46,56]$, but there are still contradictory data regarding Ki-67 as a predictive factor [57, 58]. In the GeparSixto trial, Ki-67 was not found to have an influence on the tumor response to platinum [35]. In our study, tumors with higher Ki-67 levels were more likely to reach pCR, but the test for interaction did not reveal an association of the Ki-67 level with the prediction of pCR. This implies that in TNBC it is possibly not Ki-67 itself, but other related molecular factors that predict the response to platinum.

Moreover, tumors with poor grading have been reported to show increased amounts of TILs $[50,51,59]$. High stromal TILs ( $\geq 60 \%$ ) were found in $27 \%$ of G3 tumors, compared with $12 \%$ in G2 tumors and 6\% in G1 tumors [50]. In TNBC with high TILs, pCR and prognosis were also improved for different treatments [50, 51, 59]. Furthermore, in patients with triple-negative lymphocyte-predominant $\mathrm{BC}$, the addition of platinum treatment to anthracycline treatment improved pCR more ( $74 \%$ vs $43 \%, P=0.005$ ) than in non-lymphocyte-predominant BC (34\% vs. $46 \%, P=0.08)$, although the test for interaction was not significant [51].

The present analysis did not investigate the rates of germline mutations, somatic mutations, HRD, or TILs. Nevertheless, when the published data are taken into account, it may be assumed that these factors are more frequently present in the cohort of G3 tumors. This could be the reason for higher platinum sensitivity in tumors with grade 3 and poorer efficacy of platinum in tumors with grades $1-2$, in which these factors are less important. Anthracyclines have different mechanisms of action, such as intercalation between base pairs of the DNA/RNA strand, inhibition of the topoisomerase II enzyme, generation of free oxygen radicals, interaction with histones, etc. [60, 61]. It seems that in G1 and G2 tumors, these effects of anthracyclines are more important than those of platinum. Finally, the question arises of whether the total histological score proposed by Elston and Ellis is appropriate for identifying tumors with reduced HRD or other factors of increased chemosensitivity, or whether single criteria such as gland formation, nuclear polymorphism, and mitotic count are more important for distinguishing these tumors [45].

The main weaknesses of the present study are its small sample size and the retrospective nature of the analysis. However, although all the patients were selected from clinical routine work, no unexpected associations were seen. The results of the subgroup analysis must be regarded as mainly exploratory, but the different efficacy relative to grading supports the results of other studies and might require further analysis in the future. Due to the low number of events, multivariate analyses for prediction of DFS and OS were not performed.

\section{Conclusion}

In conclusion, this retrospective study observed higher $\mathrm{pCR}$ rates after neoadjuvant therapy with platinum in TNBC patients with G3 tumors. The study indicates that platinum treatment should be considered in the subgroup of high-grade TNBC patients. The results of this study justify further research in larger prospective trials, including the assessment of grading, Ki-67, mutation status, HRD, and TILs in patients with TNBC and possibly other subtypes of $\mathrm{BC}$ as well.

\section{Abbreviations \\ BC: Breast cancer; Cl: Confidence interval; DFS: Disease-free survival; DNA: Deoxyribonucleic acid; ER: Estrogen receptor; HER2: Human epidermal growth factor receptor 2; HRD: Homologous recombination deficiency; OR: Odds ratio; OS: Overall survival; PARP: Poly-adenosine diphosphate ribose polymerase; PCR: Pathological complete response; PR: Progesterone receptor; SD: Standard deviation; TIL: Tumor-infiltrating lymphocyte; TNBC: Triple- negative breast cancer}

\section{Acknowledgments}

The authors are grateful to Michael Robertson for professional medical editing services.

\section{Funding}

We acknowledge support from the Deutsche Forschungsgemeinschaft (DFG) and Friedrich Alexander University of Erlangen-Nuremberg (FAU) within the "Open Access Publishing" funding programme. There was no further funding for the design of the study, collection, analysis, and interpretation of data and in writing the manuscript.

Availability of data and materials

The datasets are available from the corresponding author on reasonable request.

\section{Authors' contributions}

PG and PAF made substantial contributions to the conception and design of the study, to the acquisition, analysis, and interpretation of data, and to critical revision of the manuscript. MW drafted the manuscript and was involved in revising it critically for important intellectual content. CF made substantial contributions to statistical analyses, and $\mathrm{CF}$ and $\mathrm{LH}$ were involved in suggestions for manuscript revision. PG, MPL, CR, AH, MRB, AH, JP, RE, DLW, RSW, MWB, PAF, and MW were involved in the acquisition of data (patient and tumor characteristics, histopathological assessment, carrying out surgical procedures or systemic treatment). All authors gave their final approval of the version to be published, revised the manuscript critically and should have participated sufficiently in the work to take public responsibility for appropriate portions of the content. All authors agreed to be accountable for all aspects of the work in ensuring that questions related to the accuracy or integrity of any part of the work are appropriately investigated and resolved.

\section{Ethics approval and consent to participate}

This retrospective study and the anonymized scientific use of the data were approved by the ethics committee of the medical faculty of the University of Erlangen-Nuremberg. Informed consent was obtained from each individual participant included in the study.

\section{Consent for publication \\ Not applicable.}

\section{Competing interests}

PG has received honoraria from Novartis and financial support for symposia from Novartis, Roche, and PharmaMar. MPL has received honoraria from MSD and AstraZeneca. A Hartmann is member of the Editorial Board of BMC Cancer as Associate Editor. PAF has received honoraria from Roche, Amgen, Celgene, Novartis, and Pfizer. The authors declare that they have no competing interests. 


\section{Publisher's Note}

Springer Nature remains neutral with regard to jurisdictional claims in published maps and institutional affiliations.

\begin{abstract}
Author details
'Department of Gynecology and Obstetrics, Erlangen University Hospital, University Breast Center for Franconia, Comprehensive Cancer Center Erlangen-EMN, Friedrich Alexander University of Erlangen-Nuremberg, Universitätsstrasse 21-23, 91054 Erlangen, Germany. ${ }^{2}$ Department of Medical Informatics, Biometry and Epidemiology, Friedrich Alexander University of Erlangen-Nuremberg, Waldstrasse 6, 91054 Erlangen, Germany. ${ }^{3}$ Institute of Pathology, Erlangen University Hospital, Friedrich Alexander University of Erlangen-Nuremberg, Krankenhausstrasse 8-10, 91054 Erlangen, Germany. ${ }^{4}$ Biostatistics Unit, Department of Gynecology and Obstetrics, Erlangen University Hospital, Universitätsstrasse 21-23, 91054 Erlangen, Germany. 5 Institute of Diagnostic Radiology, Erlangen University Hospital, Friedrich Alexander University of Erlangen-Nuremberg, Maximiliansplatz 3, 91054 Erlangen, Germany.
\end{abstract}

\section{Received: 18 June 2017 Accepted: 9 October 2018} Published online: 29 October 2018

\section{References}

1. Robert-Koch-Institut: Krebs in Deutschland für 2013/2014. 2017, Version 11.

2. Perou CM, Sorlie T, Eisen MB, van de Rijn M, Jeffrey SS, Rees CA, Pollack JR, Ross DT, Johnsen H, Akslen LA, et al. Molecular portraits of human breast tumours. Nature. 2000;406(6797):747-52.

3. Perou CM, Borresen-Dale AL. Systems biology and genomics of breast cancer. Cold Spring Harb Perspect Biol. 2011;3(2). http://cshperspectives. cshlp.org/content/3/2/a003293.long.

4. Sorlie T, Perou CM, Tibshirani R, Aas T, Geisler S, Johnsen H, Hastie T, Eisen $M B$, van de Rijn M, Jeffrey SS, et al. Gene expression patterns of breast carcinomas distinguish tumor subclasses with clinical implications. Proc Natl Acad Sci U S A. 2001;98(19):10869-74.

5. Sotiriou C, Neo SY, McShane LM, Korn EL, Long PM, Jazaeri A, Martiat P, Fox SB, Harris AL, Liu ET. Breast cancer classification and prognosis based on gene expression profiles from a population-based study. Proc Natl Acad Sci U S A. 2003;100(18):10393-8.

6. van 't Veer $L$, Dai $H$, van de Vijver MJ, He YD, Hart AA, Mao M, Peterse HL, van der Kooy K, Marton MJ, Witteveen AT, et al. Gene expression profiling predicts clinical outcome of breast cancer. Nature. 2002;415(6871):530-6.

7. Schneeweiss A, Lux MP, Janni W, Hartkopf AD, Nabieva N, Taran FA, Overkamp F, Kolberg HC, Hadji P, Tesch H, et al. Update breast cancer 2018 (part 2) - advanced breast cancer, quality of life and prevention. Geburtshilfe Frauenheilkd. 2018;78(3):246-59.

8. Untch M, Huober J, Jackisch C, Schneeweiss A, Brucker SY, Dall P, Denkert C, Fasching PA, Fehm T, Gerber B, et al. Initial treatment of patients with primary breast cancer: evidence, controversies, consensus: spectrum of opinion of German specialists at the 15th international St. Gallen breast cancer conference (Vienna 2017). Geburtshilfe Frauenheilkd. 2017;77(6):633-44.

9. Brenton JD, Carey LA, Ahmed AA, Caldas C. Molecular classification and molecular forecasting of breast cancer: ready for clinical application? J Clin Oncol. 2005;23(29):7350-60.

10. Curigliano G, Burstein HJ, E PW, Gnant M, Dubsky P, Loibl S, Colleoni M, Regan MM, Piccart-Gebhart M, Senn HJ, et al. De-escalating and escalating treatments for early-stage breast cancer: the St. Gallen international expert consensus conference on the primary therapy of early breast cancer 2017. Ann Oncol. 2017;28(8):1700-12.

11. Hammond ME, Hayes DF, Dowsett M, Allred DC, Hagerty KL, Badve S, Fitzgibbons PL, Francis G, Goldstein NS, Hayes M, et al. American Society of Clinical Oncology/college of American pathologists guideline recommendations for immunohistochemical testing of estrogen and progesterone receptors in breast cancer. J Clin Oncol. 2010;28(16):2784-95.

12. Perou CM. Molecular stratification of triple-negative breast cancers. Oncologist. 2011;16(Suppl 1):61-70.

13. Prat A, Adamo B, Cheang MC, Anders CK, Carey LA, Perou CM. Molecular characterization of basal-like and non-basal-like triple-negative breast cancer. Oncologist. 2013;18(2):123-33.

14. Denkert C, Liedtke C, Tutt A, von Minckwitz G. Molecular alterations in triple-negative breast cancer-the road to new treatment strategies. Lancet. 2017;389(10087):2430-42
15. Wolff AC, Hammond ME, Hicks DG, Dowsett M, McShane LM, Allison KH, Allred DC, Bartlett JM, Bilous M, Fitzgibbons P, et al. Recommendations for human epidermal growth factor receptor 2 testing in breast cancer: American Society of Clinical Oncology/College of American Pathologists clinical practice guideline update. J Clin Oncol. 2013;31(31):3997-4013.

16. Bareche $Y$, Venet $D$, Ignatiadis $M$, Aftimos $P$, Piccart $M$, Rothe $F$, Sotiriou $C$. Unravelling triple-negative breast cancer molecular heterogeneity using an integrative multiomic analysis. Ann Oncol. 2018;29(4):895-902.

17. Mancini P, Angeloni A, Risi E, Orsi E, Mezi S. Standard of care and promising new agents for triple negative metastatic breast cancer. Cancers. 2014;6(4): 2187-223.

18. Bertucci F, Finetti P, Birnbaum D, Mamessier E. The PD1/PDL1 axis, a promising therapeutic target in aggressive breast cancers. Oncoimmunology. 2016;5(3):e1085148.

19. Lord CJ, Ashworth A. PARP inhibitors: synthetic lethality in the clinic. Science. 2017;355(6330):1152-8.

20. Farmer H, McCabe N, Lord CJ, Tutt AN, Johnson DA, Richardson TB, Santarosa M, Dillon KJ, Hickson I, Knights C, et al. Targeting the DNA repair defect in BRCA mutant cells as a therapeutic strategy. Nature. 2005; 434(7035):917-21.

21. Timms KM, Abkevich $V$, Hughes E, Neff C, Reid J, Morris B, Kalva S, Potter J, Tran TV, Chen J, et al. Association of BRCA1/2 defects with genomic scores predictive of DNA damage repair deficiency among breast cancer subtypes. Breast Cancer Res. 2014;16(6):475.

22. Lux MP, Janni W, Hartkopf AD, Nabieva N, Taran FA, Overkamp F, Kolberg HC, Hadji P, Tesch H, Ettl J, et al. Update breast cancer 2017 - implementation of novel therapies. Geburtshilfe Frauenheilkd. 2017;77(12):1281-90.

23. Fasching PA, Ekici AB, Wachter DL, Hein A, Bayer CM, Haberle L, Loehberg CR, Schneider M, Jud SM, Heusinger $K$, et al. Breast cancer risk - from genetics to molecular understanding of pathogenesis. Geburtshilfe Frauenheilkd. 2013;73(12):1228-35.

24. Couch FJ, Hart SN, Sharma P, Toland AE, Wang X, Miron P, Olson JE, Godwin AK, Pankratz VS, Olswold C, et al. Inherited mutations in 17 breast cancer susceptibility genes among a large triple-negative breast cancer cohort unselected for family history of breast cancer. J Clin Oncol. 2015;33(4):304-11.

25. Liedtke C, Mazouni C, Hess KR, Andre F, Tordai A, Mejia JA, Symmans WF, Gonzalez-Angulo AM, Hennessy B, Green M, et al. Response to neoadjuvant therapy and long-term survival in patients with triple-negative breast cancer. J Clin Oncol. 2008;26(8):1275-81.

26. von Minckwitz G, Untch M, Blohmer JU, Costa SD, Eidtmann H, Fasching PA Gerber B, Eiermann W, Hilfrich J, Huober J, et al. Definition and impact of pathologic complete response on prognosis after neoadjuvant chemotherapy in various intrinsic breast cancer subtypes. J Clin Oncol. 2012; 30(15):1796-804.

27. Hahnen E, Lederer B, Hauke J, Loibl S, Krober S, Schneeweiss A, Denkert C, Fasching PA, Blohmer JU, Jackisch C, et al. Germline mutation status, pathological complete response, and disease-free survival in triple-negative breast cancer: secondary analysis of the GeparSixto randomized clinical trial. JAMA Oncol. 2017;3(10):1378-85.

28. Sikov WM, Berry DA, Perou CM, Singh B, Cirrincione CT, Tolaney SM, Kuzma CS, Pluard TJ, Somlo G, Port ER, et al. Impact of the addition of carboplatin and/or bevacizumab to neoadjuvant once-per-week paclitaxel followed by dose-dense doxorubicin and cyclophosphamide on pathologic complete response rates in stage II to III triple-negative breast cancer: CALGB 40603 (Alliance). J Clin Oncol. 2015;33(1):13-21.

29. Byrski T, Gronwald J, Huzarski T, Grzybowska E, Budryk M, Stawicka M, Mierzwa T, Szwiec M, Wisniowski R, Siolek M, et al. Pathologic complete response rates in young women with BRCA1-positive breast cancers after neoadjuvant chemotherapy. J Clin Oncol. 2010;28(3):375-9.

30. von Minckwitz G, Timms K, Untch M, Elkin EP, Hahnen E, Fasching PA Schneeweiss A, Salat CT, Rezai M, Blohmer J-U, Zahm D-M, Jackisch C, Gerber B, Klare P, Kümmel S, Paepke S, Schmutzler R, Chau S, Reid J, Hartman A-R, Nekljudova V, Weber KE, Loibl S. Homologous repair deficiency (HRD) as measure to predict the effect of carboplatin on survival in the neoadjuvant phase II trial GeparSixto in triple-negativeearly breast cancer [abstract]. In: Proceedings of the 2016 San Antonio Breast Cancer Symposium. Cancer Res. 2017;77(4 Suppl):Abstract nr P1-09-02.

31. Von Minckwitz G, Loibl S, Schneeweiss A, Salat CT, Rezai M, Zahm D-M, Klare P, Blohmer J-U, Tesch H, Khandan F, Fasching PA, Jakisch C, Nekljudova V, Untch M. Abstract S2-04: Early survival analysis of the randomized phase II trial investigating the addition of carboplatin to 
neoadjuvant therapy for triple-negative and HER2-positive early breast cancer (GeparSixto). Cancer Res. 2016;76:S2-04. https://doi.org/10.1158/15387445.SABCS15-S2-04

32. Fasching PA, Loibl S, Eidtmann $H$, Tesch $H$, Untch M, Hilfrich J, Schem C, Rezai M, Gerber B, Costa SD, Blohmer JU, Fehm TN, Huober J, Liedtke C, Müller V, Nekljudova V, Weber K, Rack B, Rübner M, Wang L, Ingle JN, Weinshilboum RM, von Minckwitz G, Couch F. BRCA mutations, therapy response and prognosis in the neoadjuvant GeparQuinto study. [abstract]. In: Proceedings of the Thirty-Eighth Annual CTRC-AACR San Antonio Breast Cancer Symposium. Cancer Res. 2016;76(4 Suppl):Abstract nr S5-06.

33. Silver DP, Richardson AL, Eklund AC, Wang ZC, Szallasi Z, Li Q, Juul N, Leong $\mathrm{CO}$, Calogrias D, Buraimoh A, et al. Efficacy of neoadjuvant cisplatin in triplenegative breast cancer. J Clin Oncol. 2010;28(7):1145-53.

34. Gluz O, Nitz U, Liedtke C, Christgen M, Grischke EM, Forstbauer H, Braun M, Warm M, Hackmann J, Uleer C, et al. Comparison of neoadjuvant nab-paclitaxel +carboplatin vs nab-paclitaxel+gemcitabine in triple-negative breast cancer: randomized WSG-ADAPT-TN trial results. J Natl Cancer Inst. 2018;110(6):628-37.

35. von Minckwitz G, Schneeweiss A, Loibl S, Salat C, Denkert C, Rezai M, Blohmer JU, Jackisch C, Paepke S, Gerber B, et al. Neoadjuvant carboplatin in patients with triple-negative and HER2-positive early breast cancer (GeparSixto; GBG 66): a randomised phase 2 trial. Lancet Oncol. 2014;15(7):747-56

36. Von Minckwitz G, Hahnen E, Fasching P, Hauke J, Schneeweiss A, Salat C, Rezai M, Blohmer J-U, Zahm D, Jackisch C. Pathological complete response (pCR) rates after carboplatin-containing neoadjuvant chemotherapy in patients with germline BRCA ( $\mathrm{g}$ BRCA) mutation and triple-negative breast cancer (TNBC): results from GeparSixto. J Clin Oncol. 2014;32(15 Suppl):1005.

37. Zhang J, Powell SN. The role of the BRCA1 tumor suppressor in DNA double-strand break repair. Mol Cancer Res. 2005;3(10):531-9.

38. Bhattacharyya A, Ear US, Koller BH, Weichselbaum RR, Bishop DK. The breast cancer susceptibility gene BRCA1 is required for subnuclear assembly of Rad51 and survival following treatment with the DNA cross-linking agent cisplatin. J Biol Chem. 2000;275(31):23899-903.

39. Beheshti F, Hassanian SM, Khazaei M, Hosseini M, ShahidSales S, Hasanzadeh M, Maftouh M, Ferns GA, Avan A. Genetic variation in the DNA repair pathway as a potential determinant of response to platinum-based chemotherapy in breast cancer. J Cell Physiol. 2018;233(4):2752-8.

40. Sharma P, Barlow WE, Godwin AK, Pathak H, Isakova K, Williams D, Timms KM, Hartman AR, Wenstrup RJ, Linden HM, et al. Impact of homologous recombination deficiency biomarkers on outcomes in patients with triplenegative breast cancer treated with doxorubicin-based adjuvant chemotherapy (SWOG S9313). Ann Oncol. 2018;29(3):654-60.

41. Telli ML, Hellyer J, Audeh W, Jensen KC, Bose S, Timms KM, Gutin A, Abkevich $V$, Peterson RN, Neff C, et al. Homologous recombination deficiency (HRD) status predicts response to standard neoadjuvant chemotherapy in patients with triple-negative or BRCA1/2 mutationassociated breast cancer. Breast Cancer Res Treat. 2018;168(3):625-30.

42. Zhao EY, Shen Y, Pleasance E, Kasaian K, Leelakumari S, Jones M, Bose P, Ch'ng C, Reisle C, Eirew P, et al. Homologous recombination deficiency and platinum-based therapy outcomes in advanced breast cancer. Clin Cancer Res. 2017;23(24):7521-30.

43. Beckmann MW, Brucker C, Hanf V, Rauh C, Bani MR, Knob S, Petsch S, Schick S, Fasching PA, Hartmann A, et al. Quality assured health care in certified breast centers and improvement of the prognosis of breast cancer patients. Onkologie. 2011;34(7):362-7.

44. Kowalski C, Ferencz J, Brucker SY, Kreienberg R, Wesselmann S. Quality of care in breast cancer centers: results of benchmarking by the German cancer society and German society for breast diseases. Breast. 2015;24(2):118-23.

45. Elston CW, Ellis IO. Pathological prognostic factors in breast cancer. I. the value of histological grade in breast cancer: experience from a large study with long-term follow-up. Histopathology. 1991;19(5):403-10.

46. Fasching PA, Heusinger K, Haeberle L, Niklos M, Hein A, Bayer CM, Rauh C, Schulz-Wendtland R, Bani MR, Schrauder M, et al. Ki67, chemotherapy response, and prognosis in breast cancer patients receiving neoadjuvant treatment. BMC Cancer. 2011;11:486.

47. Sauter G, Lee J, Bartlett JM, Slamon DJ, Press MF. Guidelines for human epidermal growth factor receptor 2 testing: biologic and methodologic considerations. J Clin Oncol. 2009;27(8):1323-33.

48. Telli ML, Timms KM, Reid J, Hennessy B, Mills GB, Jensen KC, Szallasi Z, Barry WT, Winer EP, Tung NM. Homologous recombination deficiency (HRD) score predicts response to platinum-containing neoadjuvant chemotherapy in patients with triple-negative breast cancer. Clin Cancer Res. 2016;22(15):3764-73.
49. von Wahlde MK, Timms KM, Chagpar A, Wali VB, Jiang T, Bossuyt V, Saglam O, Reid J, Gutin A, Neff C, et al. Intratumor heterogeneity of homologous recombination deficiency in primary breast cancer. Clin Cancer Res. 2017; 23(5):1193-9.

50. Denkert C, von Minckwitz G, Darb-Esfahani S, Lederer B, Heppner BI, Weber KE, Budczies J, Huober J, Klauschen F, Furlanetto J, et al. Tumour-infiltrating lymphocytes and prognosis in different subtypes of breast cancer: a pooled analysis of 3771 patients treated with neoadjuvant therapy. Lancet Oncol. 2018;19(1):40-50.

51. Denkert C, von Minckwitz G, Brase JC, Sinn BV, Gade S, Kronenwett R, Pfitzner BM, Salat C, Loi S, Schmitt WD, et al. Tumor-infiltrating lymphocytes and response to neoadjuvant chemotherapy with or without carboplatin in human epidermal growth factor receptor 2-positive and triple-negative primary breast cancers. J Clin Oncol. 2015;33(9):983-91.

52. Tun N, Villani G, Ong K, Yoe L, Bo Z. Risk of having BRCA1 mutation in highrisk women with triple-negative breast cancer: a meta-analysis. Clin Genet. 2014;85(1):43-8

53. Mavaddat N, Barrowdale D, Andrulis I, Domchek S, Eccles D, Nevanlinna H, Ramus S, Spurdle A, Robson M, Sherman M. HEBON; EMBRACE; GEMO study collaborators; kCon-fab investigators; SWE-BRCA collaborators; consortium of investigators of modifiers of BRCA1/2. Pathology of breast and ovarian cancers among BRCA1 and BRCA2 mutation carriers: results from the consortium of investigators of modifiers of BRCA1/2 (CIMBA). Cancer Epidemiol Biomark Prev. 2012;21:134-47.

54. Krammer J, Pinker-Domenig K, Robson ME, Gonen M, Bernard-Davila B, Morris EA, Mangino DA, Jochelson MS. Breast cancer detection and tumor characteristics in BRCA1 and BRCA2 mutation carriers. Breast Cancer Res Treat. 2017;163(3):565-71.

55. Davies H, Glodzik D, Morganella S, Yates LR, Staaf J, Zou X, Ramakrishna M, Martin S, Boyault S, Sieuwerts AM, et al. HRDetect is a predictor of BRCA1 and BRCA2 deficiency based on mutational signatures. Nat Med. 2017;23(4): 517-25.

56. Chen X, He C, Han D, Zhou M, Wang Q, Tian J, Li L, Xu F, Zhou E, Yang K. The predictive value of Ki-67 before neoadjuvant chemotherapy for breast cancer: a systematic review and meta-analysis. Future Oncol. 2017;13(9):843-57.

57. Balmativola D, Marchio C, Maule M, Chiusa L, Annaratone L, Maletta F, Montemurro F, Kulka J, Figueiredo P, Varga Z. Pathological non-response to chemotherapy in a neoadjuvant setting of breast cancer: an interinstitutional study. Breast Cancer Res Treat. 2014;148(3):511-23.

58. Vörös A, Csörgő E, Kővári B, Lázár P, Kelemen G, Rusz O, Nyári T, Cserni G. Different methods of pretreatment Ki-67 labeling index evaluation in core biopsies of breast cancer patients treated with neoadjuvant chemotherapy and their relation to response to therapy. Pathol Oncol Res. 2015;21(1):147-55.

59. Würfel $F$, Erber $R$, Hübner $H$, Hein $A$, Lux $M$, Jud $S$, Kremer $A$, Kranich $H$, Mackensen A, Häberle L, et al. TILGen: a program to investigate immune targets in breast cancer patients - first results on the influence of tumorinfiltrating lymphocytes. Breast Care. 2018;13:8-14.

60. Nitiss JL. Targeting DNA topoisomerase II in cancer chemotherapy. Nat Rev Cancer. 2009;9(5):338-50.

61. Misteli T, Soutoglou E. The emerging role of nuclear architecture in DNA repair and genome maintenance. Nat Rev Mol Cell Biol. 2009;10(4):243-54.

\section{Ready to submit your research? Choose BMC and benefit from:}

- fast, convenient online submission

- thorough peer review by experienced researchers in your field

- rapid publication on acceptance

- support for research data, including large and complex data types

- gold Open Access which fosters wider collaboration and increased citations

- maximum visibility for your research: over $100 \mathrm{M}$ website views per year

At $\mathrm{BMC}$, research is always in progress.

Learn more biomedcentral.com/submissions 